\title{
User innovation and entrepreneurship: case studies from rural India
}

Vanita Yadav ${ }^{1 *}$ and Preeti Goyal ${ }^{2}$

\footnotetext{
* Correspondence: vanitay@gmail.com ${ }^{1}$ Strategy and Policy Area, IRMA, Anand, Gujarat 388001, India Full list of author information is available at the end of the article
}

\begin{abstract}
Innovation research has abundant literature on technologically advanced innovations and entrepreneurship. However, literature from a rural innovator and entrepreneur perspective is sparse. Therefore, we explore rural user innovation and entrepreneurship in a developing country, India. Using multiple case study research method, we study cases of five rural user innovations in detail. These rural innovators innovated to alleviate the drudgery of their lives and to fulfill their need for a low-cost local solution to a widespread rural problem. They often face a resource void for commercializing their innovations and we find that external actors can play an enabling role in filling this void. The findings of our study help propose a framework for enabling rural innovation and entrepreneurship in developing countries like India. Further, in addition to poverty alleviation, we found that there was a positive social impact on the lives of rural entrepreneurs and their community.

Keywords: User innovation; Entrepreneurship; Rural innovation; Case study; Developing country
\end{abstract}

\section{Background}

User innovation and entrepreneurship is an important phenomenon, which competes with and may displace producer innovation in many areas (Baldwin and Von Hippel 2011). There is a growing interest in this field and we know very little about its applicability in the developing economies.

Research on user innovation and entrepreneurship to date has focused almost entirely on developed economy settings (Enos 1962; Knight 1963; Freeman 1968; von Hippel 1988, 2005; Shah and Tripas 2007). The phenomenon is understudied from the developing economy's perspective. Gupta (2006) reports numerous examples of rural innovations occurring in India. However, his study does not examine these rural innovations from the user innovation perspective.

Bruton et al. (2008) suggest that there is a need to examine the applicability of existing innovation and entrepreneurship theories in a developing economy context to advance our theoretical understanding of this field. This context is quite different from that pertaining in developed economies. For example, institutional arrangements supporting markets are either absent or weak in developing economies resulting in institutional voids (Mair and Marti 2009). This is impedes entrepreneurial activities in developing countries like Bangladesh (Mair et al. 2012) and India (Khanna and Palepu 2010). 
In this paper we address this gap in the literature by examining rural innovation and entrepreneurship in India using the user innovation theoretical lens. Specifically, we ask the following research questions: (1) Why do rural users innovate? (2) How do they innovate? (3) How do they commercialize their products to become user entrepreneurs? (4) What is its impact on the individual rural user entrepreneur? (5) What is the impact of rural user entrepreneurship on the society or local community?

The paper proceeds as follows: First, we present a theoretical overview of user innovation theory and highlight the gap in literature. Next, we discuss the findings from our case studies and present a cross-case analysis. Then, we summarize our findings and discuss the implications of our study.

\section{Theoretical overview}

User innovation theory

von Hippel's (1988) work on sources of innovation reveals that users (both individuals and user firms) have developed some of the most important products and processes for their own use. He defines user innovators as a firm or individual that creates an innovation to use it. Examples of user innovation can include a surgeon inventing a new medical device for his/her use or a sports enthusiast creating new sports equipment for his/her own use.

Studies in many fields have documented the importance of user innovation. For example, in oil refining, user firms developed nearly all of the important innovations (Enos 1962). Users developed nearly 80\% of the important scientific instruments (von Hippel 1976). Users also developed majority of the major innovations in semiconductor processing (von Hippel 1988) and in sports equipment (Hienerth 2006). In British firms, considerable fractions of inventions were for in-house usage (Pavitt 1984). Literature on user innovation reports empirical evidences from various countries like USA, UK, Canada, and Netherlands. Empirical studies reveal that users ranging from $6 \%$ to 40\% develop and modify products (Baldwin and Von Hippel 2011). All this highlights the fact that users are developers of a significant number of innovations that exist in the world today. Baldwin and von Hippel (2011) argue that we are now witnessing a paradigm shift from the traditional producer innovation model to a user and open collaborative innovation model. von Hippel (1986) also suggests that needs of user innovators can be idiosyncratic or can reflect the needs of a larger population.

\section{User entrepreneurship}

We define user entrepreneurs as firms or individuals that initially create an innovation for their own use and then later commercialize the innovation for sale in the marketplace. The conventional understanding of entrepreneurship suggests that recognition of a commercial marketplace opportunity precedes prototype development (Venkataraman 1997). In contrast, the emerging literature on user innovation and entrepreneurship suggests that the process can be reverse. That is, user entrepreneurs first develop prototypes and subsequently recognize the commercialization potential of their product or service (Shah and Tripsas 2007; Haefliger et al. 2010). User innovators develop this insight into commercial potential by using and gaining experience with the product or service they have developed for their own use (Haefliger et al. 2010). 
Shah and Tripsas (2007) pp. 124 define user entrepreneurship as 'the commercialization of a new product or service by an individual or group of individuals who are also users of that product or service.' They further classify user entrepreneurs as professionaluser entrepreneurs and end-user entrepreneurs. Professional-user entrepreneurs are those individuals who use a product/service in their professional lives while remaining embedded in the organization. And end-user entrepreneurs are those individuals who use a product/service in their daily life and then commercialize it. Professional-user entrepreneurs have been studied in the ice-harvesting industry (Utterback 1994) and in probe microscopy (Mody 2006). End-user entrepreneurs have been studied in rodeo kayaking (Baldwin et al. 2006), mountain bicycle (Luthje et al. 2005), and automobile industries (Franz 2005), among others.

Research also highlights that user entrepreneurs are different from other entrepreneurs due to their direct experience with the need and prototype solutions. Although the importance of users as sources of innovations is well established in the existing literature on innovation studies (von Hippel 2005), the importance of users as a source of entrepreneurial activity is a relatively understudied area (Shah and Tripsas 2007). Shah and Tripsas (2007) argue that even though users innovate, commercialization of their innovations will be rare. Using the case of juvenile products, they suggest that users are most likely to be 'accidental entrepreneurs' and that accidental community interactions play a key role in their entrepreneurial pursuit.

User entrepreneurs derive benefits from the feedback and contributions through a collective social process. Using the example of firms founded by users of video games, Haefliger et al. (2010) suggest that user entrepreneurs derive their designs from existing products or technologies. Using the case history of rodeo kayaking, Baldwin et al. (2006) discuss how the level of entrepreneurial activity changes with changing economics of manufacturing. This is because subsequent user innovations and investment in production technology changes the nature of products and its demand.

At the macro level, Saemundsson and von Hippel (2010) study the level of user entrepreneurship in a country and how user entrepreneurs differ from other entrepreneurs in their attitudes and aspirations. Chandra and Coviello (2010) present a four-part typology of 'consumers as international entrepreneurs.' Shah et al. (2006) posit that the likelihood of users engaging in entrepreneurship is highest during the early phases of an industry lifecycle and declines rapidly over time. Furthermore, Shah and Tripsas (2007) posit that user entrepreneurship is likely to exist in industries where usage of the product or service provides enjoyment as opposed to pure economic benefits.

\section{Paucity of user innovation and entrepreneurship literature from India}

The existing literature on user entrepreneurs employs case studies from sports (Baldwin et al. 2006), specialized technology (Haefliger et al. 2010), and juvenile products (Shah and Tripsas 2007) - all examples of innovations from developed economies. There is a paucity of literature from developing economies. We carried out an extensive search in the online available databases like Proquest, EBSCO, JSTOR, and Google scholar to look for studies from rural areas in developing countries. To search, we used combinations of keywords like 'user innovation + rural/grassroots/developing country/developing economy/India', 'user entrepreneurship + rural/grassroots/developing country/developing economy/India' and searched for words in title or author supplied keywords or 
abstract. The search results either displayed no papers or put forward a few papers that were not relevant for our search criterion. To decide on relevance, we read the abstracts of these papers and then dropped those papers that were not studies of Indian user innovation or user entrepreneurship. As a result, our search yielded no papers on user innovation or user entrepreneurship from India. Our search was restricted to papers published in journals and we did not search working and conference papers. Thus, our study is an important stepping stone to theory building from a developing country perspective in the area of user innovation and entrepreneurship.

\section{Results and discussion}

We began our research by looking for evidence of user innovation and user entrepreneurship occurring in rural India. We focused primarily on rural India because $70 \%$ of the Indian population lives in rural areas (PTI Press Trust of India 2011). The next step was to understand the phenomenon in detail and examine the unique manifestations of 150 user innovation theory in the Indian context. This could be feasible only through qualitative research design, and case study emerged as the logical research method. This section discusses the findings from our case studies. We first provide a brief description of the individual cases (see Table 1 for comparative descriptions). Then, we discuss the cross-case analysis in the light of our research questions.

\section{Brief case summaries}

Innovation case 1: cotton stripper

In India, the traditional process of separating cotton lint from its shell is manual and involves separating by hand the firmly attached lint from the inner side of the cotton shell. Mansukhbhai Patel, a farmer, says that mainly women and children are employed to do this. In this process, cotton dust is emitted in the air, which is a serious health hazard. It has been found that workers exposed to an environment laden with cotton dust can become patients of byssinosis, a lung disease (Kumar 2008). Patel well understood the pain of the manual process as he was employed for cotton stripping in his childhood days.

I have seen the manual and tedious work. It was time consuming, it would take months and the rains would come and there would be huge losses for the farmers... Women and children had to do this backbreaking work and school going children were also employed in this job. I was also allocated this task. Studying or going to school was last priority. Father - mother said, 'this much work has to be done and then study or go to school'. - Patel (translated from personal interviews)

Since then, he felt that he should do something to alleviate this drudgery. He dropped from school after 9th grade due to poverty and continued to work in his cotton field. He also did many odd jobs and picked up mechanical skills by working as an electrician and mechanic in cotton mills. In 1991 to 1992, he developed a machine that could mechanically strip cotton from its shell by borrowing money from his family and friends. He tested the machine in his farm and built many prototypes before it operated as per his satisfaction. Patel finally achieved a workable commercial solution with the seventh prototype and GIAN helped in mobilizing the technical support from premier 
Table 1 Comparative case descriptions

\begin{tabular}{|c|c|c|c|c|c|c|c|}
\hline $\begin{array}{l}\text { Case } \\
\text { No. }\end{array}$ & User Innovation & $\begin{array}{l}\text { Occupation of } \\
\text { User Innovator }\end{array}$ & $\begin{array}{l}\text { Age of Innovator } \\
\text { (as on 2012) }\end{array}$ & $\begin{array}{l}\text { Family Background of the } \\
\text { Innovator }\end{array}$ & $\begin{array}{l}\text { Educational Background } \\
\text { of the Innovator }\end{array}$ & $\begin{array}{l}\text { Product Description and } \\
\text { Selling Price }\end{array}$ & $\begin{array}{l}\text { Product Units } \\
\text { Sold (till 2012) }\end{array}$ \\
\hline 1 & Cotton Stripper & $\begin{array}{l}\text { - Helper and farmer } \\
\text { in cotton fields. } \\
\text { - Also worked as an } \\
\text { electrician and mechanic } \\
\text { in cotton textile mills. }\end{array}$ & 62 & $\begin{array}{l}\text {-Belonged to a poor farmer } \\
\text { family in rural India. } \\
\text { - He hails from a small village near } \\
\text { Viramgam in Ahmedabad district } \\
\text { of Gujarat state. }\end{array}$ & $\begin{array}{l}\text { - Dropped out of school } \\
\text { due to poverty. } \\
\text { - Studied till } 9^{\text {th }} \text { grade. }\end{array}$ & $\begin{array}{l}\text { Agricultural equipment:The machine } \\
\text { mechanically strips cotton lint from semi- } \\
\text { opened or unopened pods for various } \\
\text { varieties of cotton. It can process } 800 \mathrm{~kg} \text { of } \\
\text { cotton per hour.Price: US\$ } 8000\end{array}$ & 400 units \\
\hline 2 & $\begin{array}{l}\text { Mitticool- } \\
\text { (Clay Products) }\end{array}$ & $\begin{array}{l}\text { - Potter } \\
\text { - Also, ran a tea stall } \\
\text { and worked in a factory. }\end{array}$ & 47 & $\begin{array}{l}\text { - Belonged to a poor potter } \\
\text { family in rural India. } \\
\text { - He hails from a small village } \\
\text { near Morbi in Rajkot } \\
\text { district of Gujarat state. }\end{array}$ & $\begin{array}{l}\text { - School drop out. } \\
\text { - Studied till } 9^{\text {th }} \text { grade and } \\
\text { failed in X grade. }\end{array}$ & $\begin{array}{l}\text { Clay Creations: } \\
\text { - Clay Refrigerator- (US\$ 36) } \\
\text { - Non-stick Earthen Tava (US\$ 2.75) } \\
\text { - Clay Pressure Cooker (US\$ 9) } \\
\text { - Other Clay Utensils }\end{array}$ & $\begin{array}{l}7000 \text { clay } \\
\text { refrigerators, } \\
100000 \text { clay } \\
\text { tawas and } 500 \\
\text { clay cookers }\end{array}$ \\
\hline 3 & $\begin{array}{l}\text { Bullet Santi- } \\
\text { (Motorcycle- } \\
\text { driven Ploughing } \\
\text { machine) }\end{array}$ & $\begin{array}{l}\text { - Farmer and } \\
\text { farm mechanic }\end{array}$ & 42 & $\begin{array}{l}\text { - Belonged to a poor } \\
\text { farmer family in rural India. } \\
\text { - He hails from Mota } \\
\text { Devaliya village in Amreli } \\
\text { district of Gujarat state. }\end{array}$ & $\begin{array}{l}\text { - Dropped out of } \\
\text { school due to poverty. } \\
\text { - Studied till } 5^{\text {th }} \text { grade. }\end{array}$ & $\begin{array}{l}\text { Agricultural equipment: Motorcycle-driven } \\
\text { Ploughing machine having innovative } \\
\text { attachments that can be used for various } \\
\text { farming tasks. Price: US\$ } 450 \text { for a complete } \\
\text { set of unit with } 3 \text { implements. }\end{array}$ & 500 units \\
\hline 4 & Biomass Gasifier & $\begin{array}{l}\text { - Farmer and farm } \\
\text { mechanic }\end{array}$ & 48 & $\begin{array}{l}\text { - Belonged to a poor } \\
\text { farmer family in rural India. } \\
\text { - He hails from a small } \\
\text { village called Thaldka in } \\
\text { Ganganagar district of } \\
\text { Rajasthan state. }\end{array}$ & $\begin{array}{l}\text { - Illiterate. } \\
\text { - Received no school } \\
\text { education. }\end{array}$ & $\begin{array}{l}\text { Biomass gasifier: A gasifier unit, which } \\
\text { generates producer gas from bio waste that } \\
\text { can be used to run diesel engines/ produce } \\
\text { electricity Price: US\$453 (per kilowatt) Price } \\
\text { varies from US\$2275 for } 10 \mathrm{KW} \text { unit to US } \\
\text { \$5914 for } 35 \mathrm{KW} \text { unit. }\end{array}$ & 80 units \\
\hline 5 & $\begin{array}{l}\text { Multipurpose } \\
\text { processing } \\
\text { machine }\end{array}$ & $\begin{array}{l}\text { - Rickshaw puller } \\
\text { - Farmer }\end{array}$ & 46 & $\begin{array}{l}\text { - Belonged to a poor } \\
\text { farmer family in rural India. } \\
\text { - He hails from a village } \\
\text { called Damla in Yamuna } \\
\text { Nagar district of Haryana state. }\end{array}$ & $\begin{array}{l}\text { - Dropped out of school. } \\
\text { - Studied till Xth grade. }\end{array}$ & $\begin{array}{l}\text { Food processing equipment: Multipurpose } \\
\text { processing machine, which can work as pulp } \\
\text { extractor, dry grinder, boiler or sterilizer, } \\
\text { pressure cooker. Price: Large version US\$2457 } \\
\text { and small version is US\$1183 }\end{array}$ & 25 units \\
\hline
\end{tabular}


education institutions like National Institute of Design (NID) and Indian Institute of Technology (IIT). He also obtained intellectual property rights protection for his product in India and in the USA with the help of NIF. Patel now owns five small firms with a turnover of over US\$ 0.3 million.

\section{Innovation case 2: mitticool (innovative clay products)}

Clay pottery was the traditional business of Mansukhbhai Prajapati's family living in a small village in rural India. Prajapati failed in 10th grade and dropped out of school. Due to meager financial returns, Prajapati gave up pottery. He ended up earning his livelihood by doing odd jobs at various places like running a small tea stall or working in a factory for 4 years. While working for a brick roof tiles factory, he was inspired to build a machine to make clay products with high efficiency. So, he returned back to his family occupation - pottery. The clay used for this is somewhat different than the clay used for hand pottery and it took him some time to master this clay composition. $\mathrm{He}$ began by making earthen clay pots and hot plates in 1988. Most people in rural India use clay pots to store drinking water and hot plates or tawa for cooking flat wheat bread. In rural areas, the earthen pots are a natural way of keeping drinking water cool in summers. In January 2001, an earthquake registering 7.9 on the Richter scale devastated the Indian state of Gujarat and all earthen pots of Prajapati were broken.

\section{A photographer took pictures of my broken clay pots and published in the newspaper with a headline 'Garib Ka Fridge Tut Gaya' (Refrigerator of the Poor has Broken). I thought; he is calling my pot a fridge. We also want a fridge but do not have money to purchase one... so... why don't I make a clay fridge for myself... and I started experimenting with clay to make a clay refrigerator that did not need electricity to cool.}

In 2005, my wife wanted a nonstick pan for cooking and when I went to the market to buy one, I saw the cost was INR 450 (US\$8). It was very expensive for me and I thought-can't I do something to my clay hotplates to make them nonstick. I worked on it for 1.5 years... - Prajapati (translated from personal interviews)

Prajapati created many innovative clay products like the Mitticool clay refrigerator, the nonstick clay tawa (hot plate) and the clay pressure cooker. The name of the refrigerator 'Mitticool' comes from the Hindi word mitti, which in means 'clay.' The clay refrigerator can be used to store cold water, food, fruits, and vegetables without any electricity or any artificial form of energy. It works on the simple principal of cooling by evaporation. Water from the upper chambers drips down the sides and evaporates, which leaves the inner chamber cool. It can be good alternative for people living in rural areas where electricity is not available or for those who are poor and cannot afford the conventional refrigerator. Financially, Prajapati has been able to move out of poverty and he received 25 awards including one from the President of India.

\section{Innovation case 3: Bullet Santi (motorcycle-driven ploughing machine)}

In 1994, the region of Amreli in the western part of India faced severe drought. The cost of manual labor was high and tilling the dry farmland became difficult. There was also shortage of cattle fodder and Mansukhbhai Jagani could no longer afford to use his 
cattle for tilling his farm. These difficult conditions compelled Jagani to sell his bullocks and his farming suffered. He started thinking of ways by which he could come out of this misery.

With no money and bullocks, I had no choice but to think of an alternative way to plough our 20 bighas of land. I got this idea of developing a 'Bullet Santi' from 'Chhakdas', the common mode of three-wheeler transport in Saurashtra. - Jagani (translated from personal interview)

Jagani had also worked as a farm mechanic repairing diesel engines and farming equipment. He borrowed his friend's Royal Enfield Bullet motorcycle and tried attaching a tiller to it. He created attachments using cheap and used components from foundries. The idea seemed to work and he further experimented with different ploughing attachments that could be fixed behind the motorcycle for farming. Jagani replaced the rear wheel with a set two smaller wheels and attached a metal plough behind the bike. He began using it for ploughing in his farm. It eliminated the need of bullocks or laborers for ploughing and Jagani named it 'Bullet Santi,' where Santi means 'plough.' The motorcycle had a 5.5 horsepower diesel engine and with the attachments it could be used as a multipurpose machine for ploughing, sowing, interculturing, spraying insecticides, or a small goods carrier. Other farmers also saw value in his invention and started approaching him for similar solutions.

The machine worked as a faster alternative to the traditional farming method that uses bullocks and as a cheaper alternative to modern farming methods that use tractors. In 1994, Jagani had developed the first prototype. Subsequently, the Council of Scientific and Industrial Research (CSIR) Lab in India helped Jagani improve the product design, and NIF and GIAN helped in its commercialization. His product got a patent in India and in the USA. Jagani has been able to move out of poverty and also received national level awards by NIF.

\section{Innovation case 4: biomass gasifier}

While other children went to school, Rai Singh Dahiya worked and helped his parents in their farm in rural India. He would weed and water the plants, look after the cattle, and do other jobs. They lived in a temporary or kutcha house made of mud and clay. Water would often come inside the house during rains and having a good meal was a luxury. Even though he could not attend school due to poverty, he had a keen desire to learn and was a regular listener of BBC radio for Science called Gyan-Vigyan. Dahiya had an inquisitive mind and he would often experiment with things. He would dismantle and again assemble anything that he could lay his hands on, for example, watches, clocks, radio, or farm machinery. He would often make models with mud and felt that he understood the language of machines.

In 1982, he started a brick kiln in which bricks are baked by burning the agriculture waste. He noticed that burning of biowaste in the kiln was producing gas. He thought whether he could store this gas and explore what it could be used for. Later in 1991, he opened a small workshop to repair tractors and farm equipment because he found machines fascinating and enjoyed identifying and solving problems. During 
that time, the fuel prices were going up and Dahiya felt that he must find some cheaper alternative to fuel.

LPG (liquefied petroleum gas) was becoming expensive, diesel was becoming expensive. I thought let me try to use the gas produced in my kiln to run the engine... this gas can also replace our cooking fuel and can be very cheap. - Dahiya (translated from personal interviews)

Dahiya thought about making an engine that could run on gas from farm waste or even cow dung. He made product designs using bricks and contemplated how he could make them using iron, other metal and old diesel engines. After years of experimenting, in 2001, he succeeded in running a diesel engine on biofuel by converting biomass into producer gas.

I faced lot of problems in the process. The engine would run for some time and then would stop. I had to open it, clean it, and then run again. I had no idea about filtration then... I thought about it and worked on it... Finally, in 2002, I made a fan filter and the engine ran successfully. - Dahiya (translated from personal interviews)

The unit consisted of a gasifier, which was conical in shape surrounded by a water jacket. The gasifier generated producer gas from biowaste and Dahiya used it to run diesel engines. Dahiya did not even know what to call his invention. In 2001, NIF scouted him and provided commercialization support. He has sold over 80 units of varied capacity and the latest version of the biomass gasifier is made of steel. It has the capacity to produce 1 kilowatt power to run an engine for $1 \mathrm{~h}$ from $1 \mathrm{~kg}$ of biowaste.

Dahiya has come a long way from extreme poverty to now owning property, which is a three-story building having his shops on the ground floor. He himself is illiterate and worked hard to ensure that his three children get education.

My eldest daughter is doing PhD. My younger daughter has completed MBA and my son is doing BBA. - Dahiya (translated from personal interviews)

\section{Innovation case 5: multipurpose processing machine}

Dharamveer Kamboj hails from a poor farmer family in the northern part of rural India. He studied in school until the 10th grade and then started assisting his father. Overburdened with loans, he decided to go to the nearby metropolitan city Delhi and work as a rickshaw puller to earn some money. He worked there for 2 years but had to return back to his village after meeting with an accident. He was bedridden for months and his family faced severe hardships. After recovering, he thought about growing medicinal herbs in his farm and visited the horticulture department in a small city called Ajmer in India. He had heard that there was a need for herbal plants during his stay in Delhi. Kamboj started with plants like aloe vera and stilia and built a small nursery.

Then came the problem of processing these herbal plants. He knew that there was a demand for aloe vera gel and he could make money by extracting and processing the aloe vera gel. But Kamboj did not have the money to buy the expensive machines 
existing in the market. Additionally, these machines could not carry out multiple functions that he wanted. Kamboj thought about building a processing machine something on the lines of a food processer which would not only extract pulp or juice from the plants that he was growing but also convert them into powder form. He borrowed money and struggled for 8 months in designing and building the machine. In 2005, he was able to build the first prototype. He took help of a local factory for fabrication and welding.

NIF scouted and helped commercialize his product. GIAN assisted Kamboj in product design improvement. Kamboj has made several changes in product design and the latest version is capable of extracting oil and juice from various herbs, fruits and vegetables. It can also work as pulp extractor, dry grinder, boiler, or sterilizer. It can be used to boil rice, make ketchup or puree from tomatoes, or make dry powder from spices or fruits. It can also be used to extract ripe mango pulp without breaking the seeds. Kamboj now earns a decent income per month that enables him to live comfortably and provide education to his children. He also provides employment to more than 25 people from the village in his manufacturing unit.

\section{Cross-case analysis}

\section{RQ1: why do rural users innovate?}

The common aspect found in all the five case studies was that the user innovators were poor and professionally dissatisfied. They had experienced hardships due to poverty in their lives. In case studies of Patel, Jagani, and Kamboj, we find that they innovated to automate a manual process that was time-consuming and laborious. Four case studies also reveal that the users innovated to fulfill a necessity for a low-cost solution as compared to the existing products in the market. For instance, Dahiya innovated a biofuel because the diesel was expensive, Jagni innovated a motorcycle-driven plough because tractors were very expensive, Prajapati innovated a mitticool fridge because existing market refrigerator unaffordable, and Kamboj innovated the multipurpose machine because the existing machines were expensive and offered limited functionality. However, Patel's need to innovate was driven by desire to alleviate drudgery of the manual cotton stripping process.

\section{RQ2: how did the rural users innovate?}

In this question, we tried to study the process of rural user innovation. We find that the users were well aware of their local need and the constraints of their environment. This drives them to develop an idea of a product. For example, Patel got an idea to build a machine for stripping cotton, Prajapati got an idea to build a clay-based refrigerator, Jagni got an idea to attach ploughing implements to a motorcycle, Dahiya thought of using the gas produced in his kiln, and Kamboj got an idea to build a machine on the lines of a food processor. The next step in the innovation process was to seek financial help to build the product, as all of them were poor. They primarily relied on informal means of obtaining finance either from family members or friends. All of them had little or no educational backgrounds and were not conversant with the process of obtaining financial support from financial institutions. Additionally, they had no collateral to submit to banks. After acquiring financial support from informal 
sources, they built an initial working prototype.

\section{RQ3: how did rural users commercialize their products and become entrepreneurs?}

The rural user innovators initially developed the product to meet their individual need but also thought about its commercial viability mainly to earn some money. They start using their product and show its use to other people living in their rural community. The rural innovators also tried to sell their product but were not able to successfully participate in the market and experienced a chasm. They tried to pick up business skills while on-the-job primarily through experiential learning. External organizations like NIF helped these rural innovators and they received financial support, without collateral, from NIF's Micro Venture Fund. They also receive marketing, intellectual property rights (IPR), and business development support through NIF and its partner organizations like GIAN, SRISTI, and Honey Bee network. Four rural user innovators, namely, Patel, Jagani, Dahiya, and Kamboj, received product design and development support from premier educational institutions in India with the help of NIF. As a result, they are able to improve their products and build technologically better commercial prototypes. With support from external institutions, they are able to sell the final product to more number of customers from different geographic locations in India. Some user entrepreneurs also sell their products in international markets like Dahiya received queries for his biomass gasifier from Africa, Germany, Singapore, and Pakistan. Prajapati has exported his mitticool refrigerator to Nairobi in Africa. Kamboj has exported his multipurpose processing machine to Kenya and has queries from Ethiopia.

\section{RQ4: what is the impact on the individual rural entrepreneur?}

We find that the five rural user entrepreneurs not only experience economic but also social gains. All the five rural entrepreneurs are able to generate livelihood for themselves and earn money by selling their products. All of them report that by becoming an entrepreneur they have been able to move out of poverty. In four cases, we also see increased productivity and efficiency of work. For instance, Patel reported his cotton stripper brought down cotton stripping cost from US\$ 0.02 per $\mathrm{kg}$ to US\$ 0.02 per 20 $\mathrm{kg}$. All the five user entrepreneurs state that their entrepreneurial career has impacted them at a personal level. It has helped build self-confidence and has instilled a sense of self-respect. They proudly report that their community also respects them now as they have received national level recognition through awards and media coverage. All of them report that their standard of living has improved and they are now able to provide school and college education to their children.

\section{RQ5: what is the impact of rural entrepreneurship on society or local community?}

Through this research question we tried to explore whether there was any spillover effect of their entrepreneurial career on the society at large. We find that the creation of entrepreneurs, in our case rural user entrepreneurs, offers economic, social, and environmental gains for the society. Specifically, we find that customers get access to low-cost products like the mitticool refrigerator or the motorcycle-driven plough or low-cost biofuel. Two user entrepreneurs, namely, Patel and Kamboj, report their customers have experienced economic gains as reduced cost of production after using their machines. After analyzing the interview data of user entrepreneurs and the NIF chairman, 
we find that there is also a society-level impact like employment generation, improving quality of life for the poor, health benefits, and building a sense of pride in the community of the user entrepreneur. For example, Kamboj provides employment to 25 rural villagers in his small factory. Further, many rural women who bought Kamboj's machine have generated employment for themselves by processing and selling herbal products from their homes. Mitticool refrigerators offer cold water and food storage options to the poor. The cotton stripper offers health benefits by eliminating the harmful manual procedure traditionally used for cotton stripping.

All the five user entrepreneurs state that there has been a development of social pride within their communities. In one case, we find that the user entrepreneur has brought about change in their community, for instance, Kamboj states that there has been a parivartan $k i$ lahar meaning 'a wave of change' that has enabled self-employment in whichever village his machine has reached. Finally, two case studies also reveal environmental benefits in the form of ecofriendly products like biofuel and clay-based natural refrigerators.

\section{Towards a framework of rural user innovation and entrepreneurship in India}

In this section, we discuss the findings of our study in the light of literature on user innovation theory and posit a framework of rural user innovation and entrepreneurship in India (see Figure 1). As discussed earlier, prior literature suggests that user innovation is driven by in-house use benefits (von Hippel 1988, 2005). Prior literature also indicates that innovators develop their innovation using primarily the information and resources they have (Luthje et al. 2005). Prior literature on user entrepreneurship indicates that users innovate for their own use and only later discover the commercial possibilities in their products (Shah and Tripsas 2007). Finally, prior literature indicates that 'lead' users - those ahead of an important market trend - will tend to innovate (von Hippel 1986).

In our case studies, we observed that these factors hold in the case of rural innovators in India. The innovators' need for a low-cost solution or alleviating drudgery of their lives was their key driver for innovation. In other words, necessity is indeed the

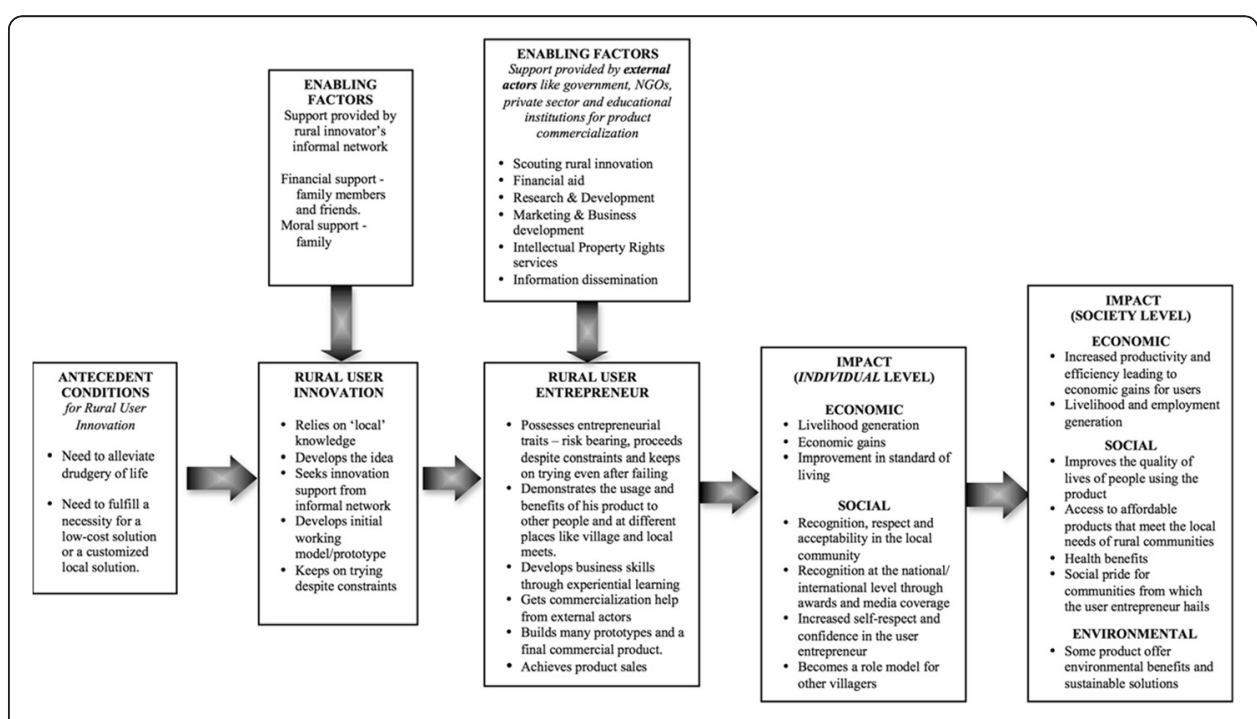

Figure 1 Results summary: framework of rural user innovation and entrepreneurship in India. 
mother of invention in the case of rural user innovators. These are proposed as antecedent conditions/factors for rural user innovation in our model of rural user innovation and entrepreneurship in India (see Figure 1).

Driven by these antecedent factors, the rural user innovates and develops a product. His understanding of the local environment and its constraints shapes the product development process. Most of the rural innovators did not have any formal education or training; yet, it is this familiarity with their environment that enabled them to develop local solutions. They understand the needs as well as the constraints of the communities and its environment. This is in concurrence with the finding of Lujthe et al. (2005) where they suggest that user innovators mostly use 'local' information both for determining the need for and for developing solutions for their innovations. Lujthe and von Hippel (2006) define local information as knowledge already in possession of the innovators or the innovators themselves have generated it.

Next, we find that some of these innovations are built on existing products that are meant for purposes other than what the original product was meant for, like Jagni modified a motorcycle for use as a farm ploughing machine. This transformation is not unique to rural user innovations as prior literature also reports transformations in other cases of user innovation. The shooting films in video games (Haefliger et al. 2010) and the transformation of a phonograph turntable from a playback device into a musical instrument (Faulkner and Runde 2009) in its own right are examples of similar innovations with technological transformations.

The antecedent factors drive the user to conceptualize the idea for an innovative solution and the user now initiates the process of developing the user innovation (Figure 1). The process of rural user innovation is an interplay of local knowledge and innovative transformations in order to seek solutions for local problems and alleviate drudgery. The rural user tries to overcome his constraints by seeking financial and moral support from family and friends. This is represented as enabling factors for rural user innovation in the model. It is import to note that at this stage, the rural user is dependent only on his informal network for support. His low educational background, poor financial conditions, and limited knowledge on how to seek finance from financial institutions limit him to reach out to only his informal network for innovation development support.

In our five cases, the innovators were lead users with respect to the important general trend - driven by 'bottom of the pyramid' demand - for extremely low-cost solutions. In each case we studied, expensive solutions existed in the marketplace for the needs each experienced - but in each case, the rural innovators were too poor to purchase these solutions. In addition, given their poverty, the solutions were not appropriately designed to suit their needs. Thus, commercial tractors did exist which could perform the same task as the Jagni-modified motorcycle, which he developed as a farm ploughing machine. Similarly, commercial gas and electric refrigerators do exist which could perform the same task as Prajapati's evaporative cooling clay refrigerator. The innovations that these five entrepreneurs developed performed the functions of existing products but filled a leading-edge marketplace demand in the sense of being well ahead on the dimension of low cost.

Going forward, having a good and useful innovation does not necessarily translate into an entrepreneurship. Entrepreneurship literature suggests that to be an 
entrepreneurial individual, one needs to possess certain core human attributes (Shane 2003) like willingness to bear uncertainty (Kihlstrom and Laffont 1979), tolerance for ambiguity (Schere 1982), or need for achievement (McClelland 1961). We find in our case studies that the rural user innovators kept on trying despite their difficult living and working conditions. They all wanted to alleviate drudgery of their lives by innovating. In other words, as an individual, they all were willing to take risk and face uncertainty. They kept on trying even after losing money or their personal belongings like their house as seen in the case of Prajapati.

Further, if we look at the traditional model of new product development, we find that it is a process that starts with the generation of ideas, which undergoes a number of iterations and finally lead to the commercial launch of new products (Cooper and Kleinschmidt 1993; Cooper 1996; Fox et al. 1998). This is in line with the findings from all our case studies. We find that the rural user develops an idea and initiates the process of user innovation by building a prototype or initial product, which undergoes a series of changes before it could be commercialized. The cotton stripper was modified seven times over a period of 10 years. The motorcycle-driven plough, biomass gasifier, mitticool refrigerator, and multicrop thresher were all modified multiple times during the commercialization process.

Our case studies also reveal that rural innovators had poor understanding of obtaining formal finance from financial institutions, little exposure to the world at large, and limited technical know-how to make advanced product design modifications. As a result, there existed a chasm, which they had to overcome in order to bring their product to market and achieve profitable sales. This chasm or void was filled by the external organizations who not only provide financial support but also other forms of support, which is required to commercialize a product. Our finding is contrary to the finding of Lettl et al. (2006) where they report that users of medical equipment technology are not only inventors but also codevelopers. These advanced users play an entrepreneurial role and themselves organize the required innovation networks to commercialize their products. In our case studies, we find that the rural users are able to organize only informal innovation networks for seeking finance and resources to build their initial product. Due to their educational and financial backgrounds, they are unable to organize formal innovation networks to grow and achieve sales in markets outside their immediate community/village. Thus, a void or a chasm impedes their market participation and some form of external institutional support is required to enable participation in larger markets.

The literature on institutional voids also suggests that in many developing economies, formal institutional arrangements that support markets are absent, weak, or fail to achieve stated goals (Mair and Marti 2009). The biggest challenge for developing economies like India is to enable participation of the poor in markets. Puffer et al. (2010) used institutional theory to study entrepreneurship in China and Russia. They report slow development of efficient and legitimate formal institutions in Russia and China resulting in institutional voids. These entrepreneurs mainly relied on informal institutional arrangements of their trusted networks to fill the void of formal institutions. In our case studies, we also find that the rural users sought help from their informal network of family and friends. This is clearly different from the case of entrepreneurs from developed economies who operate with relatively higher certainty under effective formal institutions. 
We find that external actors played an enabling role in product commercialization in our case studies. All the five rural user innovators took help from external organizations such as NIF, GIAN, SRISTI, and educational institutions in India such as IIT and others. Specifically, they got financial support, marketing and business development support, and IPR-related services from these external organizations. Therefore, in our model, we posit that the support provided by external actors like the government, nongovernment organizations, educational institutions, and private sector organizations act as critical enabling factors that can help the rural user entrepreneur cross the chasm by acquiring the required resources and skills to commercialize their product. This is a two-way interaction wherein the rural user entrepreneur primarily seeks financial support, but these external actors like NIF scout the rural innovator and extend not only financial but also marketing, business development, and legal support. We also posit that the rural user innovator is able to commercialize his product and become a user entrepreneur only when he possesses some individual level entrepreneurial traits like bearing risk and trying to build product prototypes despite all constrains (Figure 1).

After the commercialization of an innovation, the economic benefits for the entrepreneur are well documented (Wennekers and Thurik 1999; Van Praag and Versloot 2008). We found this to be true in our cases as they all were able to move out of poverty. In addition to the economic benefits, we found that there was a positive social impact on the lives of these rural user entrepreneurs. The user entrepreneurs enjoyed social recognition and also experienced greater self-esteem, social respect, and acceptability. For example, Patel's social acceptability took a dramatic turn with the success of his entrepreneurial venture. He was initially critiqued as a failure but after his entrepreneurial pursuit he became the 'pride of his community.' Furthermore, coverage of such stories by television channels like Discovery or NDTV increased confidence and self-esteem in rural user entrepreneurs.

In addition to the impact at an individual level, rural user entrepreneurship is likely to make a significant impact at the society or community level. The products innovated and commercialized for the rural level improve the users' quality of life by having access to products that are usually considered as basic necessities in developed economies. In addition, the commercialization of innovated products may also provide health benefits in the form of reduced harmful impacts as seen in the case of cotton stripper machine and the nonstick clay tawa. The use of cotton stripper increased the production and improved the quality of cotton ready for ginning, which increased profitability. This suggests that the increased efficiency and productivity with the use of the product also leads to the economic prosperity of its users. Instances of such cross-pollination would be in line with the suggestions of World Bank's published research (Dutz 2007) on increasing India's innovation potential. The report suggests that supporting networks and institutions like NIF and others can promote grassroots level rural innovations, which are likely to assist in poverty alleviation and sustainable development (Utz and Dahlman 2007).

As seen in the case of Prajapati, individuals who may have been considered ordinary on becoming successful can be a 'source of pride' for their community. On the whole, this sense of social pride is likely to lead to a feeling of well-being in communities. Furthermore, the products of rural user entrepreneurs can also offer environmental benefits and can possibly offer sustainable solutions for future generations. The case study of Prajapati's mitticool clay products and Dahiya's biomass gasifier discussed earlier is an example of environmental friendly products. 
To conclude, in our framework, we suggest that antecedent conditions motivate rural users to initiate the process of rural user innovation. This rural user innovator is likely to commercialize his products and become a rural user entrepreneur with the help of enabling factors. Moving forward, rural user entrepreneurship is likely to have an individual level as well as societal/community level impact.

\section{Conclusions}

Implications for research, practice, and policy

Innovation is seen as crucial vehicle for increasing India's growth and helping reduce poverty and rising living standards (Dutz 2007). Nearly 90\% of India's workforce is employed in the informal sector, which is typically characterized by low productivity and low-skill activities, and about $60 \%$ is employed in the informal agriculture sector. India would benefit from encouraging rural level innovation by promoting creative efforts by the poor (Utz and Dahlman 2007). To overcome institutional voids in developing countries like India, there is a need to create and strengthen formal institutional arrangements that can support rural level innovation and entrepreneurship.

We studied cases of five rural user entrepreneurs using the case study research method. From our findings and cross-case analysis, we posit a framework which suggests that rural user innovation is likely to occur when there is a strong desire to alleviate drudgery and a need to fulfill a necessity for a low-cost local solution. Further, we suggest that rural users experience a chasm/void and the commercialization of their product is more likely to occur with the help of enabling factors, such as individuals (like friends and family) and external institutions (like the government and nongovernment organizations, educational institutions, and private sector organizations).

In addition to the economic benefits to the entrepreneur, we also found that there was a positive social impact on the lives of the rural user entrepreneurs. The rural user entrepreneurs enjoyed social recognition, experienced greater self-esteem, social respect, and acceptability. Further, rural user innovation and entrepreneurship is likely to make an impact at the community/society level also. The increased efficiency and productivity with the use of the product is likely to lead to the economic prosperity for its user community. The users of such products are likely to experience improved quality of life by gaining access to affordable low-cost products meeting their local needs. Further, some of these products can also offer health benefits in the form of reduced harmful impacts of existing products/methods as seen in the case of Patel's cotton stripping machine.

Overall, our study contributes to the growing area of user innovation and entrepreneurship. It extends the applicability of user innovation theory in the context of developing economies like India. However, our findings need to be supplemented with large-scale quantitative studies to draw generalizations. In particular, policymakers can help promote entrepreneurship in rural areas by creating innovative mechanisms and institutional arrangements that facilitate rural entrepreneur's participation in markets.

\section{Methods}

We followed Yin (2003) for our case research design and Miles and Huberman (1994) for analyzing the qualitative data. 


\section{Sample and data collection}

We began our study with an online search for data on user innovation and entrepreneurship in rural India. This led us to online databases and websites of four nodal organizations for rural innovations in India, namely, National Innovation Foundation (NIF), Honeybee Network, Society for Research and Initiatives for Sustainable Technologies and Institutions (SRISTI), and Grassroots Innovations Augmentation Network (GIAN). We crosschecked the applicability of these databases for our study with four academic experts in India.

We found that these organizations maintain a database of grassroots innovations and related activities. As part of the documentation, the members of Honey Bee network go on shodh yatras, which is a 'journey of exploration' to scout for innovations from rural India (Gupta 2006). They meet villagers, farmers, and artisans individually and prepare a report on their experiences. Finally, they create a documentation of the scouted innovation, which is maintained in an electronic database.

For data collection, first we used the online databases of NIF, SRISTI, Honey Bee, and GIAN to create our sampling frame, as they have an exhaustive list of rural innovations listed in its database since year 2000. Some examples of these rural innovations include agricultural machinery, food-processing machinery, bamboo-processing machinery, dairy machinery, handlooms and textile-related devices, and herbal products. NIF has tried to file over 550 patents on behalf of its listed innovators. Out of this, 35 patents have been granted in India and 4 have been granted in USA. NIF has Micro Venture Innovation Fund (MVIF), which has provided capital to 178 projects.

Next, we searched for cases of rural innovators who had turned into entrepreneurs. Using the user innovation theory, our selection criterion for a case of user innovation and entrepreneurship was whether the fundamental definition of user innovator was applicable to that case. In other words, we checked whether the rural user entrepreneur initially invented the product for his or her own use and then commercialized the product. We selected five entrepreneurs who had received commercialization support from NIF and/or GIAN. Our sampling was purposive and we do acknowledge that there could be other instances of rural user entrepreneurs in India. Our sample, even though purposive, had a potential to offer rich insights to lay the foundation for future research in this area.

Our unit of analysis or the 'case' was an individual user entrepreneur, and we used the multiple-case design (Yin 2003, pp. 41). We conducted total 11 personal interviews. Eight in-depth personal interviews were conducted in the Indian national language 'Hindi' as the respondents were not conversant in English. Two in-depth interviews were conducted in a regional language 'Gujarati' with the help of a translator. The final interview with the NIF chairman was conducted in English. Before starting the interview process, we created an interview guide based on our research questions. The subquestions and supporting probes were also written in the interview guide to facilitate the flow of the interview. The interview guide was translated in the local language wherever required. The interviews were tape-recorded. They were later translated and transcribed in English.

Each case of the rural user entrepreneur was used to understand why he invented the $\mathrm{X}$ product, how he invented the $\mathrm{X}$ product, how he commercialized the $\mathrm{X}$ product and became an entrepreneur (with probes on understanding the process and enabling 
factors), what was its impact on him at a personal level, and was there an impact of his entrepreneurial work on the society/his local community. The interview guide used for interview with the chairman of NIF was modified to understand the larger picture of rural innovation and entrepreneurship in India. For instance, the question 'How did

Table 2 Selected coding tables

\begin{tabular}{|c|c|c|}
\hline Code & Indicators & Examples from interview transcripts \\
\hline \multirow[t]{4}{*}{ User-background } & \multirow[t]{2}{*}{ Financial situation } & $\begin{array}{l}\text { 'I belong to a poor potter family. We used to get food grains for } \\
\text { making pots.' }\end{array}$ \\
\hline & & 'I grew up in a poor farmer family.' \\
\hline & \multirow[t]{2}{*}{$\begin{array}{l}\text { Professional } \\
\text { situation }\end{array}$} & $\begin{array}{l}\text { 'I worked as a mason, this did not interest me, then I set up a tea } \\
\text { stall... after some time I worked in a factory for sometime...' }\end{array}$ \\
\hline & & $\begin{array}{l}\text { 'I worked as a mechanic and electrician since childhood and learnt } \\
\text { about machines.' }\end{array}$ \\
\hline \multirow[t]{2}{*}{$\begin{array}{l}\text { Reason for } \\
\text { innovation }\end{array}$} & $\begin{array}{l}\text { Automation of a } \\
\text { manual process }\end{array}$ & $\begin{array}{l}\text { 'The manual process of cotton stripping was very time consuming } \\
\text { and led to a lot of wastage. I always wanted to automate this } \\
\text { process.' }\end{array}$ \\
\hline & Cost of the product & $\begin{array}{l}\text { 'Poor people also have a desire to use good products, but they can't } \\
\text { afford many of these products. So, I wanted to make products which } \\
\text { the poor could also afford.' }\end{array}$ \\
\hline \multirow[t]{4}{*}{$\begin{array}{l}\text { Process-user } \\
\text { innovation }\end{array}$} & Genesis of the idea & $\begin{array}{l}\text { 'Amla was grated by hand for making ladoos and process for making } \\
\text { gulab jal was also very manual. I wanted to do something about it.' }\end{array}$ \\
\hline & Financial resources & 'My brother in law gave me money to build the cotton stripper.' \\
\hline & $\begin{array}{l}\text { Product } \\
\text { development }\end{array}$ & $\begin{array}{l}\text { 'The engine used to run for a } 3-5 \text { hours and had to be opened and } \\
\text { cleaned after that because of faulty filter. I made several changes to } \\
\text { the gassifier before it worked properly.' }\end{array}$ \\
\hline & Challenges faced & $\begin{array}{l}\text { 'There were times when there was no food for even a meal... I have } \\
\text { struggled a lot...' }\end{array}$ \\
\hline \multirow[t]{2}{*}{$\begin{array}{l}\text { Enabler-user } \\
\text { innovation }\end{array}$} & Financial support & $\begin{array}{l}\text { 'The biggest financial support I received was from my friends and } \\
\text { family.' }\end{array}$ \\
\hline & Moral support & $\begin{array}{l}\text { 'I could not have done any of this, without the support of my } \\
\text { family.' }\end{array}$ \\
\hline \multirow[t]{4}{*}{$\begin{array}{l}\text { Process-user } \\
\text { entrepreneurship }\end{array}$} & $\begin{array}{l}\text { Business } \\
\text { development }\end{array}$ & $\begin{array}{l}\text { 'I have exported to many countries including Singapore, South } \\
\text { Africa, Germany and Kenya.' }\end{array}$ \\
\hline & $\begin{array}{l}\text { Demos of the } \\
\text { product }\end{array}$ & $\begin{array}{l}\text { 'I took the machine to Churu for a demonstration and I got an } \\
\text { export order from that.' }\end{array}$ \\
\hline & Sales & 'I have a turnover of around Rs. 1 Crore.' \\
\hline & $\begin{array}{l}\text { Role of external } \\
\text { organizations }\end{array}$ & 'NIF was a very big support- they helped with patent, money...' \\
\hline \multirow{5}{*}{$\begin{array}{l}\text { Enabler-user } \\
\text { entrepreneurship }\end{array}$} & Financial help & 'NIF provided Rs. 2.5 lakh.' \\
\hline & IPR help & 'NIF helped with patent of the product.' \\
\hline & Marketing help & 'NIF arranged for demos of my product at many exhibitions.' \\
\hline & Recognition help & 'It is because of NIF that I got the President's award.' \\
\hline & $\begin{array}{l}\text { Product } \\
\text { development help }\end{array}$ & $\begin{array}{l}\text { 'NIF has helped with the redesign of the multi-processing machine } \\
\text { so that it can process milk products also.' }\end{array}$ \\
\hline \multirow[t]{2}{*}{ Impact - individual } & Economic & 'Financially today I am very comfortable.' \\
\hline & Social impact & $\begin{array}{l}\text { 'If you type "Mansukhbhai" on Google, I am on the top of the list. I } \\
\text { have become famous as "Mitticool"'. }\end{array}$ \\
\hline \multirow[t]{3}{*}{ Impact - society } & Economic & $\begin{array}{l}\text { 'There are many women in my village who are using this machine to } \\
\text { make herbal products.' }\end{array}$ \\
\hline & Social impact & $\begin{array}{l}\text { 'Every village this machine has gone to there has been a "wave of } \\
\text { change".' }\end{array}$ \\
\hline & Environment impact & $\begin{array}{l}\text { 'The gassifier emits no pollution and is a very good alternative to } \\
\text { diesel.' }\end{array}$ \\
\hline
\end{tabular}


Table 3 Sources of data for the case studies

\begin{tabular}{|c|c|c|c|c|c|c|c|}
\hline Case & $\begin{array}{l}\text { Personal interviews } \\
\text { with user entrepreneurs }\end{array}$ & $\begin{array}{l}\text { Personal interview } \\
\text { with NIF Chairman }\end{array}$ & $\begin{array}{l}\text { NIF database } \\
\text { records }\end{array}$ & $\begin{array}{l}\text { GIAN and SRISTI website } \\
\text { data }\end{array}$ & $\begin{array}{l}\text { Newspaper } \\
\text { articles }\end{array}$ & Magazine/Internet articles & $\begin{array}{l}\text { Other data (videos on TV and } \\
\text { Internet) }\end{array}$ \\
\hline \multirow[t]{2}{*}{1} & $x$ & $x$ & $x$ & $x$ & $x$ & $x$ & $x$ \\
\hline & & & & & Hindu & $\begin{array}{l}\text { business.rediff.com; Forbes; } \\
\text { theweekendleader.com; } \\
\text { creativityatgrassroots.wordpress.com }\end{array}$ & Times Now TV \\
\hline \multirow[t]{2}{*}{2} & $x$ & $x$ & $x$ & $x$ & $x$ & $x$ & $x$ \\
\hline & & & & & Economic Times & $\begin{array}{l}\text { business.rediff.com; Forbes; } \\
\text { creativityatgrassroots.wordpress.com }\end{array}$ & Discovery channel; NDTV \\
\hline \multirow[t]{2}{*}{3} & $x$ & $x$ & $x$ & $x$ & $x$ & $x$ & $x$ \\
\hline & & & & & Economic Times & $\begin{array}{l}\text { theweekedleader.com; Forbes; } \\
\text { business.rediff.com; } \\
\text { creativityatgrassroots.wordpress.com }\end{array}$ & video.india.com \\
\hline \multirow[t]{2}{*}{4} & $x$ & $x$ & $x$ & $x$ & $x$ & $x$ & $x$ \\
\hline & & & & & $\begin{array}{l}\text { Times of India; } \\
\text { Hindu }\end{array}$ & creativityatgrassroots.wordpress.com & NIF youtube video \\
\hline \multirow[t]{2}{*}{5} & $x$ & $x$ & $x$ & $x$ & $x$ & $x$ & $x$ \\
\hline & & & & & Tribune & $\begin{array}{l}\text { India Today; FnBnews.com; } \\
\text { business.rediff.com; } \\
\text { creativityatgrassroots.wordpress.com }\end{array}$ & Documentary on youtube \\
\hline
\end{tabular}


you commercialize the X product?' was modified to 'How did the innovators listed in NIF database commercialize their products? What was the role of NIF and other organizations in this process?' These questions explored the impact and outcome of NIF's work at a national level.

\section{Data reduction and coding}

To begin with, we created high-level categories or codes deductively from user innovation and entrepreneurship theory to explore our research questions wherein codes were developed for user background, user innovation, enablers for innovation, user entrepreneurship, enablers for user entrepreneurship, and outcome of user entrepreneurship. These codes were further refined inductively using the data collected through personal interviews. The list of codes with few examples from translated interview transcripts is included in Table 2 of the paper.

\section{Multiple sources of data and triangulation}

Yin (2003) emphasizes that the strength of case study is in using a variety of evidence ranging from documents, reports, interviews, and observations. To strengthen our case study, we used a variety of evidence for data triangulation, which helped validate information from the interviews (Maxwell 1996). Our study includes primary data from personal interviews and secondary data from various sources like national level databases, company documents, reports, newspapers, and Internet sources (see Table 3). After each interview, we created individual case memos summarizing the interview. The primary data for each interview was triangulated with secondary data available from different sources listed in Table 3. Finally, we then created individual case summaries from the triangulated data.

Competing interests

The authors declare that they have no competing interests.

\section{Authors' contributions}

VY conceived the research and worked on it during a Fulbright funded research fellowship year at MIT. Both VY and PG together worked on the paper, PG collected primary data from innovators, and WY collected primary data from chairman. Both WY and PG collected secondary data and analysed the primary and secondary data. Both drafted and coordinated the paper. Both authors read and approved the final manuscript.

\footnotetext{
Acknowledgements

We greatly acknowledge the support provided by the Fulbright Foundation -USIEF, Prof. Iqbal Z. Quadir and MIT's Legatum Center for conducting this study. We are thankful to Prof. Eric von Hippel and Prof. Susan Silbey of MIT for their review and continuous guidance while writing this paper. We would like to thank all the respondents - Mr. Patel, Mr. Prajapati, Mr. Jagani, Mr. Dahiya, and Mr. Kamboj for their participation in our research study. We are also thankful to Dr. R.A. Mashelkar and Prof. Anil Gupta for their support and input.
}

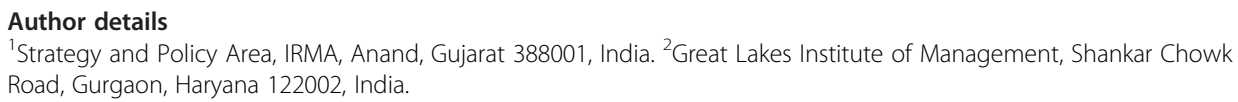


Chandra, Y, \& Coviello, N. (2010). Broadening the concept of international entrepreneurship: 'consumers as international entrepreneurs'. Journal of World Business, 45(3), 228-236.

Cooper, RG. (1996). Overhauling the new product process. Industrial Marketing Management, 25(6), 465-482.

Cooper, RG, \& Kleinschmidt, EJ. (1993). Screening new products for potential winners. Long Range Planning, 26(6), 74-82.

Dutz, MA (Ed). (2007). Unleashing India's innovation: toward sustainable and inclusive growth. Washington D.C.: World Bank Publications.

Enos, JL. (1962). Petroleum progress and profits: a history of process innovation. Cambridge: MIT Press.

Faulkner, P, \& Runde, J. (2009). On the identity of technological objects and user innovations in function. Academy of Management Review, 34(3), 442-462.

Fox, J, Gann, R, Shur, A, von Glahn, L, \& Zaas, B. (1998). Process uncertainty: a new dimension for new product development. Engineering Management Journal, 10(3), 19-27.

Franz, K. (2005). Tinkering: consumers reinvent the early automobile: Philadelphia: University of Pennsylvania Press.

Freeman, C. (1968). Chemical process plant: innovation and the world market. National Institute Economic Review, 45(August), 29-51.

Gupta, AK. (2006). From sink to source: the Honey Bee Network documents indigenous knowledge and innovations in India. Innovations: Technology, Governance, Globalization, 1(3), 49-66.

Haefliger, S, Jager, P, \& Von Krogh, G. (2010). Under the radar: industry entry by user entrepreneurs. Research Policy, 39(9), $1198-1213$.

Hienerth, C. (2006). The commercialization of user innovations: the development of the rodeo kayak industry. R\&D Management, 36(3), 273-294.

Khanna, T, \& Palepu, KG. (2010). Winning in emerging markets: a road map for strategy and execution. Cambridge MA: Harvard Business Press.

Kihlstrom, RE, Laffont, JJ. (1979). A general equilibrium entrepreneurial theory of firm formation based on risk aversion. The Journal of Political Economy, 719-748.

Knight, KE. (1963). A fast sort of country: a study of technological innovation: the evolution of digital computers. Graduate School of Industrial Administration. Pittsburgh: Carnegie Institute of Technology.

Kumar, S. (2008). Cotton dust - impact on human health and environment in the textile industry. Textile Magazine, January. http://www.fibre2fashion.com/industry-article/9/831/cotton-dust-impact-on-human-health-and-environmentin-the-textile-industry2.asp. Accessed 8 June 2012.

Lettl, C, Herstatt, C, \& Gemuenden, HG. (2006). Users' contributions to radical innovation: evidence from four cases in the field of medical equipment technology. R\&D Management, 36(3), 251-272.

Luthje, C, Herstatt, C, \& von Hippel, E. (2005). User-innovators and 'local' information: the case of mountain biking. Research Policy, 34(6), 951-965.

Mair, J, \& Marti, I. (2009). Entrepreneurship in and around institutional voids: a case study from Bangladesh. Journal of Business Venturing, 24(5), 419-435.

Mair, J, Marti, I, \& Ventresca, MJ. (2012). Building inclusive markets in rural Bangladesh: how intermediaries work institutional voids. Academy of Management Journal, 55(4), 819-850.

Maxwell, JA. (1996). Qualitative research design: an interactive approach. Thousand Oaks, CA: Sage.

McClelland, D. (1961). The achieving society. New York: The Free Press.

Miles, MB, Huberman, AM. (1994). Qualitative data analysis: an expanded sourcebook. Sage

Mody, CCM. (2006). Corporations, universities, and instrumental communities: commercializing probe microscopy, 1981-1996. Technology and Culture, 47(1), 56-80.

Pavitt, K. (1984). Sectoral patterns of technical change: towards a taxonomy and a theory. Research Policy, 13(6), 343-373.

PTI (Press Trust of India). (2011). 70\% Indians live in rural areas: census. Business Standard. http://www.business-standard. com/india/news/70-indians-live-in-rural-areas-census/141379/on. Accessed 15 March 2012

Puffer, SM, McCarthy, DJ, \& Boisot, M. (2010). Entrepreneurship in Russia and China: the impact of formal institutional voids. Entrepreneurship Theory and Practice, 34(3), 441-467.

Saemundsson, R, \& von Hippel, E. (2010). Entrepreneurship by user-innovators: how prevalent is it and how do their attitudes and aspirations differ from other entrepreneurs? (interactive paper). Frontiers of Entrepreneurship Research, 30(6), Article 20.

Schere, J. (1982). Tolerance of ambiguity as a discriminating variable between entrepreneurs and managers. Academy of Management Best Paper Proceedings, 42, 404-408.

Shah, SK, \& Tripsas, M. (2007). The accidental entrepreneur: the emergent and collective process of user entrepreneurship. Strategic Entrepreneurship Journal, 1, 123-140.

Shah, S, Agarwal, R, \& Audretsch, D. (2006). The knowledge context \& the entrepreneurial process: Academic, user, and employee entrepreneurship. Working Papers.

Shane, SA. (2003). A general theory of entrepreneurship: the individual-opportunity nexus: Edward Elgar Pub.

Utterback, JM. (1994). Mastering the dynamics of innovation: Harvard Business Press.

Utz, A, \& Dahlman, C. (2007). Promoting inclusive innovation. In MA Dutz (Ed.), Unleashing India's innovation: toward sustainable and inclusive growth (p. 105). Washington, DC: World Bank.

Van Praag, M, \& Versloot, P. (2008). The economic benefits and costs of entrepreneurship: a review of the research. Foundations and Trends in Entrepreneurship Theory and Practice, 4(2), 65-154.

Venkataraman, S. (1997). The distinctive domain of entrepreneurship research. Advances in Entrepreneurship, Firm Emergence and Growth, 3(1), 119-138.

von Hippel, E. (1976). The dominant role of users in the scientific instrument innovation process. Research Policy, 5(3), 212-239.

von Hippel, E. (1986). Lead users: a source of novel product concepts. Management Science, 32(7), 791-805.

von Hippel, E. (1988). The sources of innovation. New York: Oxford University Press.

von Hippel, E. (2005). Democratizing Innovation: the MIT Press.

Wennekers, S, \& Thurik, R. (1999). Linking entrepreneurship and economic growth. Small Business Economics, 13(1), $27-56$.

Yin, RK. (2003). Case study research: design and methods. Sage. 